\title{
Role of Intercellular Adhesion Molecule-1 (ICAM-1) of Community Acquired Pneumonia in Mansoura University Hospitals (MUHs)
}

\author{
Tahani . A.M * ,Mohammed . F.EL-K ${ }^{* *}$, Ghada .M . EL-Nady ${ }^{* *}$, Olfat.M.W. \\ Zoology Department, Faculty of Science, Immunolgy Department, Mansoura \\ University*. \\ Microbiology Department ,Faculty of Medicine, Mansoura University**.
}

\begin{abstract}
Background:Pneumonia is an inflammation of the lung that is most often caused by infection with bacteria, viruses, or other organisms. Occasionally, inhaled chemicals that irritate the lungs can cause pneumonia, Community-acquired pneumonia (CAP) is defined as pneumonia not acquired in a hospital or a long-term care facility. Despite the availability of potent new antimicrobials and effective vaccines, ICAM-1 is a cytokine inducible adhesion molecule expressed on the cells of multiple lineages at sites of inflammation.
\end{abstract}

Key words:Pneumonia, community acquired pneumonia, ICAM-1.

\section{Introduction:}

Intercellular adhesion molecule (ICAM)-1, a member of the immunoglobulin supergene family, is expressed on a variety of leukocytes and endothelial cells (Springer, 1990). Release of cytokines at sites of inflammation causes cell activation and upregulation of ICAM-1 (Rothlein et al., 1991) Pneumonia, on the other hand, is a major cause of death due to infectious diseases worldwide (Pinner et al, 1996). Bacterial pathogens commonly enter the lung via aspiration from the pharynx which happens during sleep (Huxley et al, 1978). In the face of this persistent exposure to microbial pathogens, the lung has a complex group of protective mechanisms so that repeated lowlevel entry of bacteria in the peripheral lung only rarely results in pneumonia (Green et al, 1977). In addition to cytokines, enhanced expression of cell adhesion molecules (CAMs) such as intercellular adhesion molecule-1 (ICAM-1), E-selectin, or platelet-endothelial cell adhesion molecule-1 (PECAM-1) plays an important role in the pathophysiology of infection. It has been thought that the expression of ICAM-1 on the type I aleveolar epithelial cell (AEC) surface plays an important role in host defense through the enhancement of inflammatory cell antimicrobial activity against bacteria, for example Klebsiella pneumonia. Study of adhesion molecules has been limited in pneumonia, particularly community-acquired pneumonia (Lo et al, 1991). The aim of the presnt study was to determine whether the concentrations of the intercellular adhesion molecule ICAM-1 could be related to clinical status, bacterial

pathogens, and diagnosis them as potential markers of the severity of infection.

\section{Patient and Methods:}

Patients :This study was conducted on 50 cases. Ages of cases ranged from 4 to 60 years. ( patient 40 and control 10), were hospitalized in Mansoura University Hospitals.

Sample collection: Sputum samples were collected in sterile container. Under complete aseptic conditions samples were transmitted immediately to the laboratory of microbiology at diagnostic and infection control unit (MDICU) in Medical microbiology and immunology department, and were subjected to the various examination or kept at $4^{\circ} \mathrm{C}$ (Cheesbrough et al., 2000).

\section{Methods :}

1-sputum cultures:A standard calibrated loop $(0.01 \mathrm{ml})$ was flamed thoroughly and allowed to cool without touching any surface. The sputum samples were mixed thoroughly. The loop was inserted vertically into sputum to ensure the proper amount of specimen adhered 
to the loop. The loopful of sputum was spreaded onto blood-chocklet-mackonky agar plates by touching the center of the plate, onto which the inoculum was spreaded in a line across the diameter of the plate. Then without flaming or reentering sputum, the loop was drawn across the entire plate, crossing the first inoculums streak numerous times at right angles. The plate was then turned 90 degree and the inoculum was spreaded to cover the entire surface. Plates were incubated for 48 hours at $37^{\circ} \mathrm{C}$. Colonies were counted on each plate. The number of colonies is multiplied by 100 to determine the number of microorganisms per $1 \mathrm{ml}$ of the original specimen. A count of $100000 / \mathrm{ml}$ or more indicated infection. A count of 10000-100 $000 / \mathrm{ml}$ indicated infection or contamination. A count less than $10000 / \mathrm{ml}$ indicated contamination, the samples and reagents were allowed to equilibrate to room temperature (18 $\mathrm{C}^{0}$ to $25 \mathrm{C}^{0}$ ) before commencing the assay. The reagents and samples were thoroughly mixed before used by gentle agitation.

\section{2-ELIZA Methods :}

- $100 \mu \mathrm{l}$ of anti-ICAM-1 conjugate were pipetted (Choe et al., 2000 )

\section{Results:}

A number of 40 bacterial isolates have been isolated from sputum culture of patients which showed positive growth on blood, choclete and Macconkey. These isolates have been classified according to their morphological feature and gram stain into two groups as follow

Group (A): include 3 isolates which are gram negative. Group (B): include 37 isolates which are gram positive and 10 cases as a control which show no bacteria.

Table (1) shows : 3 patients of Age (4-10) have klebsiella pneumonia divided to 1 male , 2 female , 6 patients of age (11-20) have staph aureus, streptococcus ( $\alpha$-haemolytic) divided to 4 male, 2 female. 7 patients of age (21-30) have streptococcus $(\alpha)$, MRSA 4 male, 3 female. 7 patients of age (31-40) have staph aureus, streptococcus $(\alpha), 2$ male , 5 female. 9 patients of age (41-50) have MRSA, streptococcus $(\alpha), 4$ male , 5 female. 8 patients of age (51-60) have streptococcus $(\alpha)$, divided to 5 male , 3 female,

Table 2 shows: 10 cases control have no isolated bacteria,

Table 3 shows: frequency of isolate bacteria towards the various antimicrobial agents used have (A) Klebsiella pneumonia which divided to 1 male it's frequency $33.3 \%$ and 2 female it's frequency $66.6 \%$ (B) streptococcus $(\alpha)$ which divided to 13 male it's frequency $48.1 \%$ and 14 female it's frequency $51.8 \%$ (C) staph aureus which divided to 2 male it's frequency $50 \%$ and 2 female it's frequency $50 \%$ (d) MRSA which divided to 4 male it's frequency $66.6 \%$ and 2 female it's frequency $33.3 \%$.,

Table 4 shows: Klebsiella spp give sensitive with Amikacin, Gentamicn, Imipenem, Aztreonam, Ciprofloxecin ofloxacin and Give resistant with Cefalor and Augmentin.

1- Staphylococcus aureus give sensitive with Gentamicin, Imipenem, Vancomycin, Cefalor, Trimethoprism and Meronem and give resistant with penicillin, Augmentin and Cefuroxime.

2- Streptococcu SPP $(\alpha)$ give sensitive with Imipenem, Penicillin, Vancomycin, Cefalor ofloxacin, Augmentin and resistant with Trimethoprism.

3- MRSA give sensitive with vancomycin, Meronem and resistant with Methicillin.

Table 5 and table 6 show detect ICAM-1 level in patient and control and the result was icam-1 level in patients more than in control so Icam-1 have an important role with pneumonia, Table 6 showed that Data were quantitative and test of normality was performed by Kolmoyorov-smirnov test and all data were normal, test was used to detected difference between case and control group. All the results were considered significant if $\mathrm{P}<$ 0.05 .

Calculation of mean, standerd deviation and range of the test groups explain that all the results in patient are more than in control. 
Table (1) : Isolated microbes from patients at different Hospitals

\begin{tabular}{|c|c|c|c|l||}
\hline \multirow{2}{*}{ Age } & \multirow{2}{*}{ No } & \multicolumn{2}{|c|}{ Sex } & \multicolumn{1}{|c|}{ Bacterial isolates } \\
\cline { 3 - 5 } & & Male & Female & \multicolumn{1}{||}{} \\
\hline $4-10$ & 3 & 1 & 2 & Klebsiella Pneumonia \\
\hline $11-20$ & 6 & 4 & 2 & $\begin{array}{l}\text { Staphylococcus aureus, Streptococcus }(\alpha- \\
\text { haemolytic }) .\end{array}$ \\
\hline $21-30$ & 7 & 4 & 3 & Streptococcus $(\alpha)$, MRSA. \\
\hline $31-40$ & 7 & 2 & 5 & Staph aureus, Streptococcus $(\alpha)$. \\
\hline $41-50$ & 9 & 4 & 5 & MRSA, Streptococcus $(\alpha)$, staph aureus. \\
\hline $51-60$ & 8 & 5 & 3 & Streptococcus $(\alpha)$. \\
\hline
\end{tabular}

Table (2) :Isolated control from hospitals.

\begin{tabular}{|l|l|l|}
\hline Age & No & Bacterial isolates \\
\hline$(4-60)$ & 10 & 0 \\
\hline
\end{tabular}

Table(3): Total count of microbial isolates and their frequency of occurrence from patients.

\begin{tabular}{|l|c|c|c|c|c|}
\hline \multicolumn{1}{|c|}{ Bacterial isolates } & Male & \% & Female & \% & Total \\
\hline Klebsiella Pneumonia & 1 & 33.3 & 2 & 66.6 & 3 \\
\hline Streptococcus ( $\alpha)$ & 13 & 48.1 & 14 & 51.8 & 27 \\
\hline staphylococcus aureus & 2 & 50 & 2 & 50 & 4 \\
\hline MRSA & 4 & 66.6 & 2 & 33.3 & 6 \\
\hline
\end{tabular}


Table (4): Sensitivity of isolate bacteria.

\begin{tabular}{|c|c|c|c|c|}
\hline Antibiotic & $\begin{array}{c}\text { Klebsiella } \\
\text { SPP }\end{array}$ & $\begin{array}{c}\text { Staphylococcus } \\
\text { aureus }\end{array}$ & $\begin{array}{c}\text { Streptococcus } \\
\text { SPP }(\alpha)\end{array}$ & MRSA \\
\hline Amikacin & $S$ & - & - & - \\
\hline Gentamicin & $S$ & $S$ & - & - \\
\hline Imipenem & $\mathrm{S}$ & $S$ & $\mathrm{~S}$ & - \\
\hline Penicillin & - & $\mathrm{R}$ & $S$ & - \\
\hline Aztreonam & $\mathrm{S}$ & - & - & - \\
\hline Ciprofloxacin & $S$ & - & - & - \\
\hline Vancomycin & - & $S$ & $\mathrm{~S}$ & $\mathrm{~S}$ \\
\hline Cefalor & $\mathrm{R}$ & $S$ & $S$ & - \\
\hline Methicillin & - & - & - & $\mathrm{R}$ \\
\hline Ofloxacin & $\mathrm{S}$ & - & S & - \\
\hline Trimethoprism & - & $\mathrm{S}$ & $\mathrm{R}$ & - \\
\hline Augmentin & $\mathrm{R}$ & $\mathrm{R}$ & $S$ & - \\
\hline Cefuroxime & - & $\mathrm{R}$ & - & - \\
\hline Meronem & - & S & - & $\mathrm{S}$ \\
\hline
\end{tabular}

$\mathrm{R}$ : resistance

S: sensitivity 
Table (5): sICAM-1 in serum measured by ELISA expressed as $\mathrm{ng} / \mathrm{ml}$ in patients.

\begin{tabular}{|c|c|c|c|}
\hline \multicolumn{4}{|c|}{ Patients } \\
\hline No. & sICAM level & No & $\overline{\text { sICAM level }}$ \\
\hline 1 & 7.5 & 21 & 5.5 \\
\hline 2 & 6 & 22 & 4 \\
\hline 3 & 4 & 23 & 3 \\
\hline 4 & 5 & 24 & 7.5 \\
\hline 5 & 9 & 25 & 9 \\
\hline 6 & 8 & 26 & 10 \\
\hline 7 & 8 & 27 & 3 \\
\hline 8 & 6.5 & 28 & 4.5 \\
\hline 9 & 10 & 29 & 6 \\
\hline 10 & 4.5 & 30 & 7 \\
\hline 11 & 5 & 31 & 8.5 \\
\hline 12 & 6.5 & 32 & 7 \\
\hline 13 & 8 & 33 & 6.5 \\
\hline 14 & 7.5 & 34 & 4 \\
\hline 15 & 10 & 35 & 2.5 \\
\hline 16 & 4 & 36 & 9 \\
\hline 17 & 3.5 & 37 & 4.5 \\
\hline 18 & 8.5 & 38 & 5 \\
\hline 19 & 9 & 39 & 7 \\
\hline 20 & 7 & 40 & 8 \\
\hline
\end{tabular}


Table (6): sICAM-1 in serum measured by ELISA expressed as $\mathrm{ng} / \mathrm{ml}$ in control.

\begin{tabular}{||c|c||}
\hline \multicolumn{2}{||c||}{ Control } \\
\hline No. & sICAM level \\
\hline 1 & 0.7 \\
\hline 2 & 0.65 \\
\hline 3 & 1 \\
\hline 4 & 1.6 \\
\hline 5 & 0.8 \\
\hline 6 & 0.7 \\
\hline 7 & 2 \\
\hline 8 & 1.2 \\
\hline 9 & 0.9 \\
\hline 10 & 0.65 \\
\hline
\end{tabular}

Table (7): Mean, standard deviation and range of the test groups.

\begin{tabular}{|c|c|c|}
\hline & Patients & Control \\
\hline Mean & 6.48 & 1.02 \\
\hline Std. Deviation & 2.13 & 0.46 \\
\hline Minimum & 2.5 & 0.65 \\
\hline Maximum & 10 & 2 \\
\hline Range & 7.5 & 1.35 \\
\hline
\end{tabular}

Pvalue $<0.0001 * *$

CI 95\% (4.08-6.83)

\section{Statistical analysis:}

SPSS V.11 windows Xp .Data were quantitative and test of normality was performed by Kolmoyorov-smirnov test and all data were normal, student test was used to detected difference between case and control group. All the results were considered significant if $\mathrm{P}<0.05$. 


\section{Discussion:}

In this study the isolated causative organisms were compared, We found the highest incidence to be alpha hemolytic streptococcus (27\%) which comes in partial agreement with alpha hemolytic streptococcus to be the second most common microorganisms isolated from sputum culture in community acquired pneumonia ( CAP) at a rate of $10 \%$. Other micro-organisms like staph aureus, MRSA and klebsiella pneumonae caused less percentage in CAP as noted by other investigators who reported more incidence in health care associated pneumonia as (File, 2003).We have demonstrated the rise of sICAM-1 serum levels in patients with CAP. This observation confirms the role of this adhesion molecule in lung infection or inflammation contributing to the pathogenesis of CAP. This observation needs to be pooled together to design future experiments to determine the relevance of differential sICAM-1 processing on lung infection as (Lai et al., 2004). To better understand the mechanisms of lung inflammation in CAP, we evaluated the levels of sICAM-1 in patients with CAP caused by bacterial pathogens as proved by positive sputum culture. We hypothesized that ICAM-1 could play a role in CAP and is involved in recruitment of neutrophils to the site of inflammation. Thus we measured the level of sICAM-1 in serum of patients with CAP. The levels of sICAM-1 have been found to be higher in our patient group as compared with those of the control group, Previous studies have reported elevated levels of sICAM-1 in serum, bronchoalveolar lavege and CSF in association with various diseases (Lai et al., 2004). There are fewer studies showing the relationship between sICAM-1 and CAP. Our results come in agreement with (Sessler et al., 1995) who reported increased levels of circulating sICAM in adult patients with sepsis, and found positive correlations between levels of circulating sICAM and intensity of sepsis and severity of shock and subsequent organ failure have been reported. (Fill et al., 2003) demonstrated a tendency toward higher circulating levels of SICAM in ventilator associated pneumonia when it was associated with the presence of severe sepsis or septic shock. Moreover, (Lai et al., 2004) provided evidence that serum levels of sICAM-1 are increased in acute bronchiolitis which further confirms the role of adhesion molecules involved in the pathogenesis of lung infection.

\section{Conclusion:}

We have demonstrated the rise of SICAM-1 serum levels in patients with CAP. This observation confirms the role of this adhesion molecule in lung infection or inflammation contributing to the pathogenesis of CAP. This observation need to be pooled together to design future experiments to determine the relevance of differential sICAM-1 processing on lung infection.

\section{References:}

1- Cheesbrough M (2000): Biochemical test to identify bacteria. In Cheesbrough, M., ed. Laboratory practice in tropical countries; $2: 63-70$. Cambridge university press, $\mathrm{u} \mathrm{k}$.

2- Cho DH, Song HK, Kong HS et al. (2000): Ligation of ICAM-1 moleucle inhibits target cell - induced granules exocytosis of interleukin-12 activated natural killer cell. Cell lmmunol., 199: 1.

3- Collee JG, Fraser AG, Marmion BP and Simmons A. (1996a): practical medical microbiology 14 .Ed. Churchil livingstone New York, London, Tokyo.

4- File TM. (2003): Community-acquired pneumonia. Lancet ; 362:1991-2001.

5- Green GM, Jakab GJ, Low RB, and Davis GS (1977): Defense mechanisms of the respiratory membrane. Am.Rev.Respir.Dis.; 115, 479-514.

6- Huxley EJ, Viroslav J, Gray WR and Pierce AK (1978): Pharyngeal aspiration in normal adults and patients with depressed consciousness. Am. J Med; 64, 564-568.

7- Lai CC, Tai HY, Shen HD, Chung WT, Chung RL, Tang RB. (2004): Elevated levels of soluble adhesion molecules in sera of patients with acute bronchiolitis. J Microbiol Immunol Infect. ; 37(3):153-6.

8- Lo SK, Lee S, Ramos RA, Lobb R, Rosa M, ChiRosso G and Wright SD (1991): Endothelialleukocyte adhesion molecule 1 stimulates the adhesive activity of leukocyte integrin CR3 (CD1 $\mathrm{lb} / \mathrm{CD} 18$, Mac-1, alpha $\mathrm{m}$ beta 2) on human neutrophils. J Exp. Med; 173, 1493-1500.

9- Pinner RW, Teutsch SM, Simonsen L, Klug LA, Graber JM, Clarke MJ and Berkelman RL (1996): Trends in infectious diseases mortality in the United States. JAMA; 275, 189-193.

10- Rothelin R, Mainolfi EA, Czajkowski $M$ and Marlin SD (1991): A form of circulating ICAM-1 in human serum. J Immunol.; 147: 3788-3793.

11- Sessler CN, Windsor AC, Schwartz M, Watson L, Fisher BL, Sugerman HJ and Fowler I (1995): Circulating ICAM-1 is increased in septic shock. 
Role of Intercellular Adhesion Molecule-1 (ICAM-1)....

Am. J. Respir. Crit. Care Med. 151: 1420-1427.

12- - Springer TA (1990): Adhesion receptors of the immune system. Nature; 346, 425-434.

13- Wegner CD, Gundel RH, Reilly P, Hayne N, Letts
LG and Rothlein R (1990): Intercellular adhesion molecule-1 (ICAM-1) in the pathogenesis of asthma. Science 247: 456-459. 


\section{دور أيكام -1 في مرضى الالتهاب الرئوى

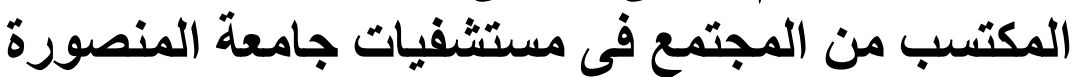

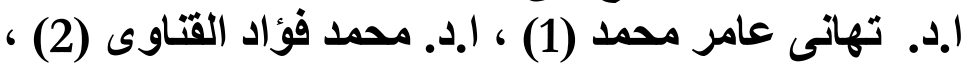

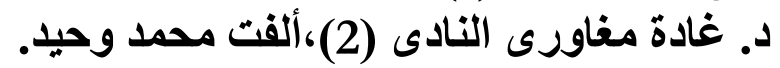

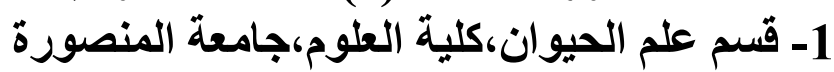 \\ 2- قسم الميكروبيولوجى والمناعة الطبية، كلية الطب، جامعة المنامة المنصورة}

$$
\begin{aligned}
& \text { الالتهاب الرئوي هو التهاب ميكروبي للرئة ويمكن تقسيم الالتهاب الرئوي كالأتي }
\end{aligned}
$$

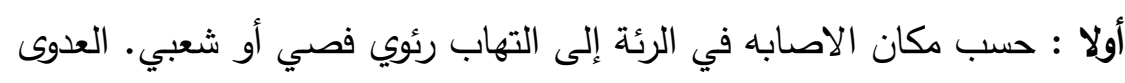

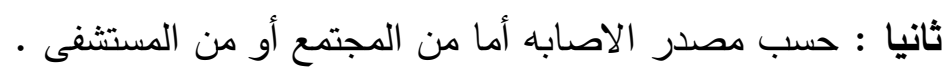

ثالثا: حسب وجود عامل مساعد مثل الفيروسات أو دمار في لسان المزمار أو أن المريض كبير السير في السن أو أو أون

عنده مرض مزمن .

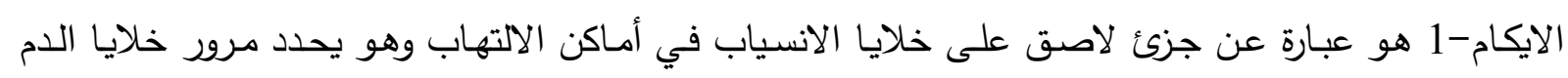

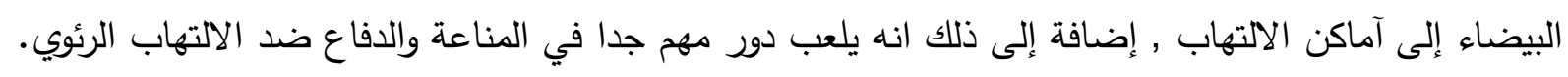

$$
\text { وقد لخصت الاراسة الحالية على الاتى : }
$$

أخذ 40 حالة مرضية من مختلف مستشفيات جامعة المنصورة وكذللك 10 حالات غير الإنير مصابة وسليمة تتراوح

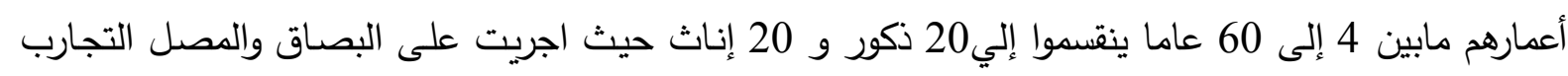

أولا: انواع مختلفة من البكتريا المؤديه الى الالتهاب الرئوى.

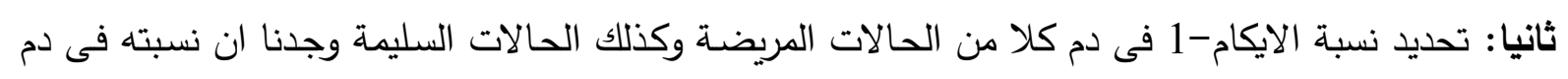

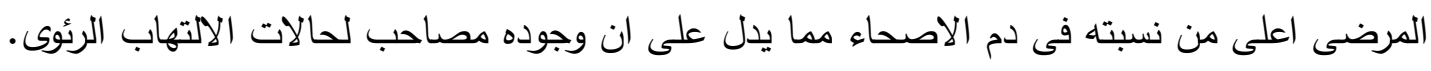

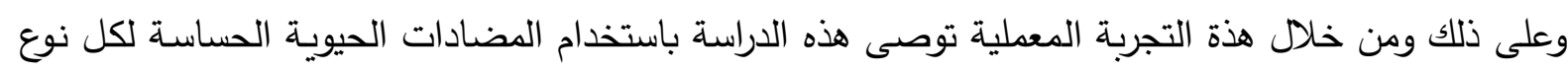

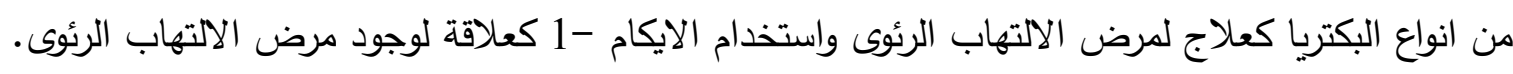

